\title{
Determinants of Audit Fees: Evidence from Lebanon
}

\author{
Walid El-Gammal \\ Correspondence: Walid El-Gammal, Assistant Professor, Department of Finance and Accounting, Lebanese \\ American University, P.O.Box:13-5053, Chouran, Beirut, Lebanon. E-mail: walid.elgammal@lau.edu.lb
}

Received: July 30, 2012

Accepted: August 27, 2012

Online Published: October 16, 2012

doi:10.5539/ibr.v5n11p136

URL: http://dx.doi.org/10.5539/ibr.v5n11p136

\begin{abstract}
This paper studies the views of external auditors and client's representatives (accountants, financial controllers and internal auditors) about the factors that affect determining audit fees and provides evidence whether these factors are related to audit firm characteristics or the client firm characteristics. A sample of 80 respondents provided the empirical data for this research by answering a self administered questionnaire. To conduct data analysis descriptive statistics, means, standard deviation and Mann-Whitney $\mathrm{U}$ test were used. The outcome of the study provides a vital insight into the determinants of audit fees from a developing country like Lebanon. It was found that all the pre-suggested determinants of audit fees are extremely important or important. Both external auditors and client representatives groups agree that the most important factor affecting determining amount of audit fees is whether the audit firm is one of the big four or notand the least important factor is the size of the audit firm based on the number of its employees. The results also show that the degree of importance of each determinant of audit fees is homogenous among the two groups of respondents.
\end{abstract}

Keywords: audit fees, auditee size, auditee complexity, auditee risk, auditee profitability, auditor size, auditor reputation, competition, Big-Four

\section{Introduction}

Audit fees can be defined as the amounts of fees (wages) charged by the auditor for an audit process performed for the accounts of an enterprise (auditee), the determination of the audit fees is based on the contract between the auditor and the auditee in accordance with time spent on the audit process, the service required, and the number of staff needed for the audit process. It should be mentioned that audit fees are normally determined before starting the audit process.

There is a growing trend in recent years in accounting about discussing the issue of audit fees, how do auditors determine the amount of fees required from the auditee. This is an important question that needs an answer. Prior research tried to examine whether determining the audit fees is affected by the audit company attributes (like size, reputation, experience, competition, industry specialization and whether it is from the big four) or by the client's company characteristics (auditee attributes like size, complexity risk, and profitability).

Most of the prior studies which presented empirical evidence of the effect of the attributes of audited companies on the audit fees, focused mostly on developed economies (UK: Taylor \& Baker, 1981; Haskins \& Williams, 1988; Chan, Ezzamel \& Gwilliam, 1993; Ezzamel, Gwilliam \& Holland, 1996; Iyer, 1996; Chung \& Narasimhan, 2002; Ezzamel, Gwilliam \& Holland, 2002; Neimi, 2002; Simon \& Taylor, 2002; Australia: Francis, 1984; Francis \& Stokes, 1986; Craswell, Francis \& Taylor, 1995; Craswell \& Francis, 1999; Canada: Chung \& Lindsay, 1988; Anderson \& Zeghal, 1994; Ireland: Haskins \& Williams, 1988; Japan: Taylor, 1997; New Zealand: Firth, 1985; Mike, Mike \& Muhammad, 1997; Norway: Firth, 1997).

Nevertheless, a limited number of studies have related to emerging economies (Jordon: Naser \& Nuseibeh, 2007; Bahrain: Joshi \& Al-Bastaki, 2000; Qatar: Kutob \& Al-Khater, 2004; Bangladesh: WaresulKarim \& Moizer, 1996; Hong Kong: Simon, Teo \& Trompeter, 1992; Sandra \& Patrick, 1996; India: Simon, Ramanan \& Dugar, 1986; Dugar, Rahmanan \& Simon, 1995; Malaysia: Simon et al., 1992; Singapore: Low, Tan \& Koh, 1990; Simon et al., 1992; South Korea: Taylor, Simon \& Burton, 1999; South Africa: Simon, 1995).

Apart from the studies undertaken by Joshi \& Al-Bastaki (2000), Naser \& Nuseibeh 2007 and Kutob \& Al-Khater (2004), no other empirical study on the factors that influence audit fees in the Middle East has been carried out. Thus, the importance of this study comes from the fact that it is the first study that provides evidence on the determinants of audit fees in Lebanon, also it will help the audit firms a lot in determining the required 
audit fees from the auditee firms.

There is an important point that should be emphasized here which is that, all the prior research are based on that, the researcher had an access to the audit fees figure which is normally published in the annual reports of most of the auditee companies. The main problem of the present study is that the researcher was not able to find the audit fees figure as there is no a strict law in Lebanon that can enforce companies (even listed companies in the stock exchange ) to publish the audit fees figure. Also the researcher was not able to find it in an informal way through contacting friends. But because the researcher has a motive to examine what are the factors that can affect determining audit fees figure in a country like Lebanon, he thought to ask different types of respondents (external auditors, client representatives) about their attitudes regarding a pre-suggested determinants of audit fees based on prior research.

\section{Literature Review}

The present study examines the drivers and determinants of audit fees in Lebanon. Based on prior studies, the determinants of audit fees can be generally classified into two major categories: client attributes (Auditee attributes) and auditor attributes. It should be noted that, the client attributes have received great attention in prior research. They include the characteristics of size, complexity, risk, and profitability of the firm being audited (Auditee). Consistent with the theory on audit effort and litigation, audit fees tend to increase with an increase in the client's size (Simunic 1980), risk (Stice 1991), complexity (e.g., Hackenbrack \& Knechel, 1997), and profitability (e.g., Hay, Knechel \& Wong, 2006).

As mentioned before, audit company attributes are also considered important drivers of audit fees. Size, reputation, experience, competition, industry specialization and whether it is from the Big Four are aspects of the audit company that influence audit fees as many prior studies suggested that audit fees increase with the Audit firm's Size (Francis, 1984; Palmrose, 1986), reputation (Larcker \& Richardson, 2004, Gonthier \& Schatt, 2007), experience, industry specialization (Pearson \& Trompeter, 1994; Craswell et al., 1995; Cullinan, 1998) and whether it is one of the Big Four (Palmrose, 1986; Francis \& Simon, 1987; Butterworth \& Houghton, 1995). However, Audit fees decreases with the increase in competition, the greater the number of competitors the lower the audit fees are charged (e.g., Maher, Tiessen, Colson \& Broman, 1992; Hay et al. 2006).In the next part, the researcher will define each of the attributes in details accompanied by the predicted effect of audit fees based on prior studies' findings and then based on this theoretical foundation, hypotheses of the present study will be developed.

\subsection{Client Attributes}

\subsubsection{Client Size (Auditee Size)}

Based on the prior studies, it can be concluded that, the auditee size is the most important factor that influences audit fees, it is usually measured by total assets, revenues, sales and number of employees of the Client Firm. The size of auditee has a direct impact on the auditors' work, and the time spent in the auditing process. Larger clients require more audit services than smaller clients, more time needed; hence we would expect that these large clients pay higher fees per dollar of size relative to smaller clients in the industry (Palmrose, 1986; Carson, Fargher, Simon \& Taylor, 2004). Hence, there is a positive relationship between audit fees and auditee size. (Simunic, 1980; Low et al.,1990; Chan et al., 1993; Carson et al., 2004).

\subsubsection{Client Complexity (Auditee Complexity)}

Complexity of the auditee can be measured by the number of branches and subsidiaries of the firm locally and internationally (subsidiaries in foreign countries). It is argued that the more complex the client firm is, the greater the number and the more diversified the subsidiaries and operations are; which necessitate more audit work; therefore, audit firms charge higher audit fees. Sandra \& Patrick (1996) showed that auditors of highly complex firms often charge high audit fees in examining and evaluating the firms financial statements. According to them, foreign subsidiaries have to abide by a variety of legislative and proficient requirements for disclosure, which necessitates further audit testing, requiring more time and additional manpower to complete the audit process. This implies that the companies have to bear additional charges for audit work. Therefore, auditee complexity has a positive correlation with the audit fees (Simunic, 1980; Low et al., 1990; Chan et al., 1993; Firth, 1997; Butterworth \& Houghton, 1995; Carson et al., 2004).

\subsubsection{Client Risk (Auditee Risk)}

Audit risk is considered an important factor in determining the audit fees. Audit risk measures the odds of an auditor issuing an unqualified judgment on materially misstated financial statements (AICPA, 1983, part 2). 
Sandra and Patrick (1996) used gearing (clients' debt ratio) and liquidity ratios to determine the client's risk. The audit risk can be calculated by the following factors or ratios: current assets / total assets, treasury, long-term debt / total assets, income before tax / total assets (Carson et al., 2004; Joshi \& Al-Bastaki, 2000). The most preferred risk measure is the Debt ratio. It is defined as the percentage of long-term debt to total assets. It measures the company's ability to pay off its incurred debt. If Debt Ratio is relatively high, the long-term financial structure of the client's firm will be unstable, and the firm may not be able to pay off its debt in a proper behavior which may lead to a lower credit rating. In general, risk (debt ratio) is higher for companies that have endured financial losses, leading to higher possibility of bankruptcy or decline in stock price, and therefore larger probability of legal actions against both the client and auditor. Auditors need to do more work to reduce any potential litigation against them, the more the work and time needed to finish the auditing process the greater the audit fee is. Therefore, Audit fees are positively associated with the clients' risk (Francis \& Simon, 1987, Craswell \& Francis, 1999).

\subsubsection{Client Pofitability (Auditee Profitability)}

The Client's firm profitability is considered as an important indicator of management performance also its efficiency in allocating available resources. The auditee profitability can be known by finding the income or loss figure shown in the income statement (Firth, 1985; Simon et al., 1986; Chung \& Lindsay, 1988; Low et al., 1990; Dugar, Ramanan \& Simon, 1995; and Waresul \& Moizer, 1996).There are many profitability ratios that can be used as a measure of the auditee profitability such as return on assets (ROA), return on equity (ROE), return on capital employed (ROCE), return on investment (ROI). Companies reporting high levels of profits will be subject to precise audit testing of their revenues and expenses and this will result in higher audit fees (Joshi \& Al Bastaki, 2000). Most of the prior research done indicate that the amount of audit fees is significantly influenced by the profitability ratio (Sandra \& Patrick, 1996).

\subsection{Audit Firm Attributes}

\subsubsection{Auditor Size}

Audit firm size is an important aspect of the audit firm that determines the audit fee. The Auditor Size is frequently measured based on the company's assets, market share and the number of employees. Choi, Kim, Kim \& Zang (2010) investigated the relationship between office size, audit quality and audit pricing, and determined that office size is positively associated with audit quality, and that large offices charge higher audit fees and provide higher quality audits. Similarly Francis \& stokes (1984) and Palmrose (1986) explained the strong relationship between auditor fees and audit company size.

\subsubsection{Experience}

The experience of the audit firm can be considered as an important attribute that influence determining the amount of audit fees. Studies reveal that years of professional experience of the audit firm would increase the audit fees charged by the audit firm. (Ferguson, Francis \& Stokes, 2003).

\subsubsection{Reputation}

Reputation of the audit office is the perception that some audit firms can provide higher quality auditing than others, which is one of the most important factors affecting the audit service pricing (e.g., Larcker \& Richardson, 2004; Gonthier \& Schatt, 2007). Firms which have invested in reputation capital (e.g., employee training programs and advertising) suggests a much higher success rate of the audit firm (Che-Ahmad \& Houghton, 1996), and therefore it may be able to obtain a return on its investment through placing higher audit fees for their services. So this means that, the better the reputation of the audit firm the more is the demand on its audit services and the higher audit fees are.

\subsubsection{Competition}

Competition among audit office can be considered as one of the factors affecting the audit service pricing, this is consistent with the study of Maher et al. (1992), their study found that an increase in the number of Audit firms between 1977 and 1981 lead to a significant decrease in real audit fees. The results of this study were consistent with those of Hay et al. (2006) study which stated that the degree of competition between audit firms for market share is an important determinant of audit fees and is inversely proportional to it.

\subsubsection{Industry Specialization}

There are lots of studies that tried to study the effect of auditor industry specialization (i.e., expertise) on audit fees (Pearson \& Trompeter, 1994; Craswell et al., 1995; Cullinan, 1998); these studies have found that an audit 
premium is received by auditors with a specialism in a particular industry. Also, researchers have examined other audit markets that are less dominated by the Big 6. Cullinan (1998) studied the effect of industry expertise on audit fees in a market in which the Big 6 firms have a relatively small market share, the US multi-employer pension plan market. The results of the study revealed that non-Big 6 firms with industry expertise received a fee premium over non-specialist firms, whereas Big 6 firms with larger market shares did not.

\subsubsection{Big-Four}

Clients would pay more to the international big firms due to their Brand name and the higher audit quality provided. Prior studies (Simon et al., 1992) find that the Big Eight or Big Five, now the Big Four (Ernst \& Young, Deloitte, PricewaterhouseCoopers (known as PwC) and KPMG) audit firms receive premium fees in many countries compared to non-Big Four (Palmrose, 1986; Francis \& Simon, 1987; Butterworth \& Houghton, 1995). The Big Four are the biggest audit firms in the world and due to their financial strength and expertise that they have they are able to provide higher quality audit. A number of important studies comprising the United States of America market, supported the idea that big international auditing companies (Big-Four) made audits of higher quality than the other (DeAngelo, 1981). Hence, based upon research findings for USA and other countries, such as the UK (e.g. Chan et al., 1993) and Australia (Butterworth \& Houghton, 1995; Craswell et al., 1995), this factor is expected to have a positive relationship with the audit fees.

The previous review and discussion of prior studies help to set pre-suggested factors that can affect determining amount of audit fee and hence provide the basis for developing the hypotheses of the present study.

Hypothesis one: Each of the suggested determinants of audit fees thought to be of high importance for both groups: external auditors, and client representatives (financial controllers, accountants and internal auditors).

Hypothesis two: The degree of importance of each determinant of audit fees is homogenous among both groups: external auditors and client representatives (financial controllers, accountants and internal auditors).

\section{Auditing Profession in Lebanon}

The Lebanese Government after the civil war has made big efforts to align national corporate financial reporting requirements with International Accounting Standards (IAS). "In November 1995, and according to law no. 364 of 1994, a new professional association was created under the name of the Lebanese Association of Certified Public Accountants (LACPA)". Its objectives were defined as follows: "To protect the profession and strive for its improvement; to develop a spirit of mutual support; to realize scientific studies; to prepare and propose accounting principles and audit standards". The LACPA was the result of enormous efforts for professional recognition and replaced the previously existing "Union of Licensed Accountants", under the supervision of the ministry of labor. Nevertheless, the licensing requirements for the accounting and the auditing professions were not settled for many years after 1995 (Longuenesse, 2006). However, all applicants for the Lebanese Association for Certified Public Accountants who pursued license to practice were certified without examination.

It should be noted that there is no enforcement mechanism exists to ensure IAS compliance, except in the banking sector. Even though, in 1996, the Minister of Finance adopted IAS (with exceptions) as the national standards to be followed by all entities in the preparation of financial statements. While IAS is highly adapted to these publicly owned firms, it is generally more complicated than necessary for small- and medium-size enterprises, placing an excessive burden on them. Although many audit firms make effort to perform audits in accordance with International Standards on Auditing (ISA), quality of audits varies significantly. The Order on Auditing, issued by the Minister of Finance, does not cover regulation or supervision of the auditing profession and does not mention enforcement regulations or the monitoring of ISA compliance (World Bank, 2003).

International Standards on Auditing are applicable for the audit of listed companies and banks. The rules of the Beirut Stock Exchange and the Banking Control Commission require that the financial statements of all listed companies and all local banks should be audited in accordance with ISA. Also there is enforcement by law that all banks should be audited jointly by two external auditors, one of them should be from the big-four and the other could be from the local Lebanese audit firms. Based on interviews made with some external auditors, the researcher found that the amount of audit fees for the same number of hours of work, paid to the big-four is higher than those paid to the local Lebanese audit firms. A recent study by Sidani (2007) in Lebanon about the auditing profession in Lebanon and how society looks at the role of the auditor revealed a significant difference in the perceptions of the role of the auditor in respect of fraud detection. This expectation gap was in terms of auditor roles and responsibilities which reflects the fact that many users do not have a proper understanding of the profession. These facts along with others lead to a continuous pressure on auditing professionals in Lebanon 
"to serve the proper image of an auditor being an independent, autonomous and ethical figure, free from undue pressures and unjustifiable demands” (Sidani, 2007).

\section{Methodology}

This study was based on the results of a survey conducted in Lebanon. A questionnaire was designed to collect data related to the determinants of audit fees in Lebanon. The sample selected comprised of external auditors, and Client representatives (accountants, financial controllers and internal auditors of the auditee firm), in other words all the parts involved in the auditing process from inside and outside the auditee firm. A total of 150 questionnaires were distributed to employees of 3 of the Big 4, of middle-sized CPA firms and leading banks, of which 80 were answered with a response rate of $54 \%$. Of the respondents $57.5 \%$ were external auditors, and $42.5 \%$ were client representatives. It should be noted that, the researcher had used self-administered questionnaire in order to increase the response rate. The response rate would have been much lower if the researcher had used mailing approach rather than direct in-person contact. In addition experience with the Lebanese culture indicates that the direct contact is a more effective and efficient way to collect data than indirect contact. Also the researcher tried to get more information about auditing profession in Lebanon through direct contact with external auditors.

The questionnaire contains two parts, the first consists of questions asking the respondents about their filed work and working experience. The second part contains questions regarding 12 pre-suggested determinants (factors) of audit fees based on prior studies. Respondents are asked to rate each factor using the likert scale from strongly disagree (1), to strongly agree (5).

This study can be considered as an exploratory research, which aims to identify the most important factor that affect determining the amount of audit fees as perceived by the different groups of respondents. Prior studies talked about separate attributes but did not consider the relative importance of these attributes relative to each other. It should be emphasized again that no prior study had examined the determinants of audit fees in Lebanon before the present research. To conduct data analysis, descriptive statistics, means, standard deviation and Mann-Whitney U test were used.

\section{Results}

The following table summarizes the SPSS output of means of different groups concerning each factor of the determinants of audit fees.

The respondents had to rate the importance of each factor on a likert scale from 1 to 5 . With score of 1 or 2 meaning that the factor does not affects audit fees and scores of 4 and 5 meaning that the factor highly affects audit fees. The average score is 3 , a mean score above this average for a factor means that the surveyed group thinks that the corresponding factor is of relative importance in determining audit fees. Table 1 below shows that, the external Auditors strongly agree that there are three factors which are of great importance in increasing audit fees, attributes which scored an average of more than 4 on the likert scale. (Audit firm is one of the big-four, reputation of the audit firm and client complexity risk). It can be concluded that the Audit Company being one of the Big-Four is considered as the most important attribute that affects audit fees according to the views of external Auditors. The other factors (attributes) can affect determining the amount of audit fees, such attributes scored an average of more than 3 but less than 4 on likert scale. Here is their order based on their relative importance in affecting determining audit fees figure.

1- Size of the client firm based on client's company total assets, and number of years of professional experience of the audit company (both factors got the same average mean score).

2- Specialized in the client's industry.

3- Client Business's Risk.

4- Size of the client firm based on the number of employees working in the company compared to others.

5- Size of the audit firm based on the Audit Company's market share in Lebanon.

6- Level of competition between the Audit Firms.

7- Client profitability.

8- Size of the audit firm based on the number of employees working in the audit company compared to others. 
Table 1. Means variances

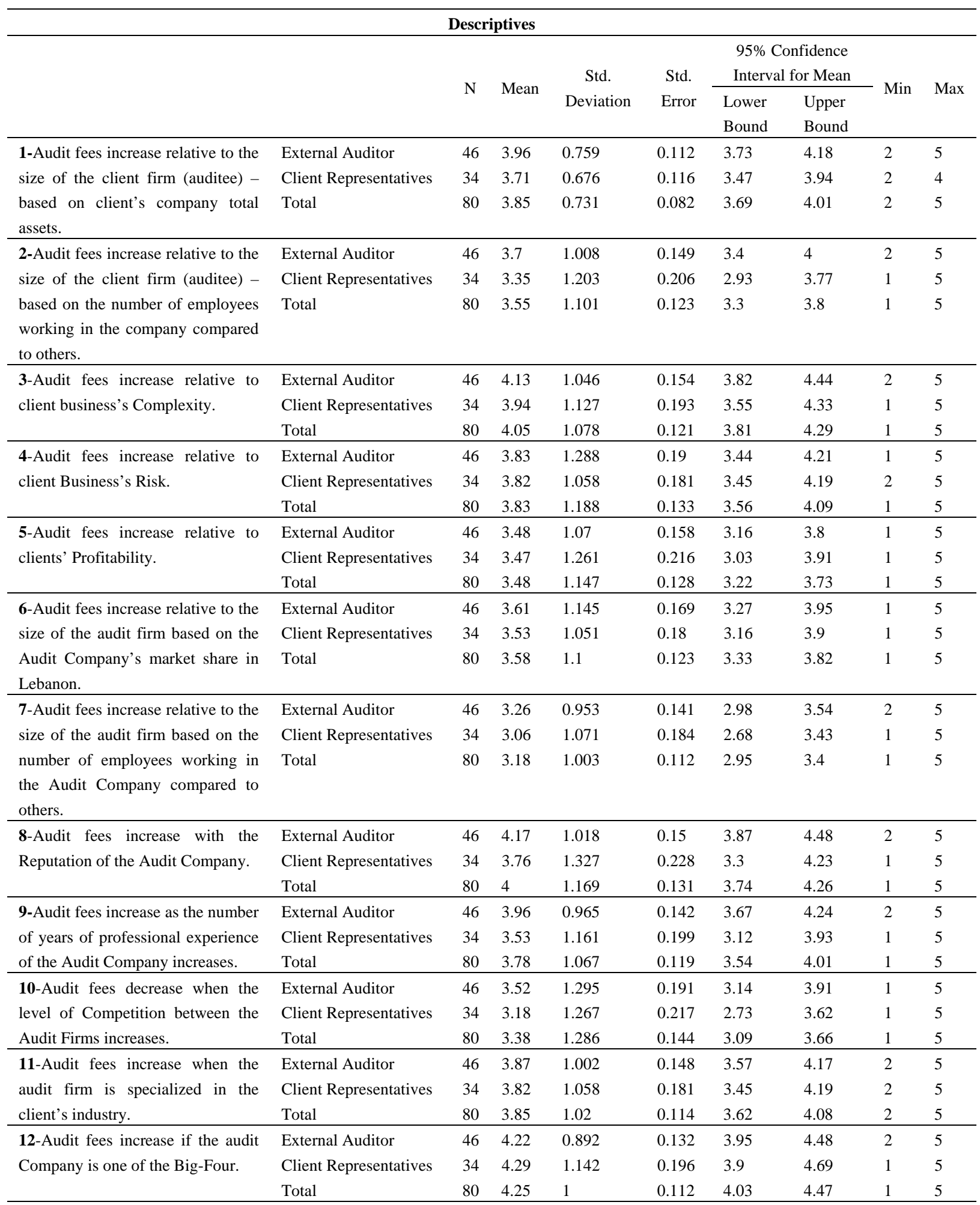

Regarding the other group of respondents (the client representatives), they strongly agree that there is only one attribute which is of great importance in increasing audit fees (mean score is higher than 4), which is whether the audit company is one of the big-four. It should be noted that both external Auditors and the client representatives groups strongly agree about the importance of this attribute in increasing audit fees. From the view point of the client representative group, the other factors can affect determining amount of audit fees, such factors scored an average of more than 3 but less than 4 on likert scale. Here is their order based on their relative importance in 
affecting determining audit fees figure.

1- Client business complexity.

2- Client business risk and specialization in client's industry.

3- Reputation of audit company.

4- The size of the client firm based on client's company total assets.

5- Size of the audit firm based on the Audit Company's market share in Lebanon and number of years of professional experience of the audit company.

6- Client' profitability.

7- Size of the client firm based on the number of employees working in the company compared to others.

8- Level of competition between the audit firms.

9- Size of the audit firm based on the number of employees working in the Audit Company compared to others.

It can be concluded that the size of the audit firm based on its number of employees can be considered as the least important factor in affecting audit fees number from view point of both the external auditors and client representatives groups.

This means that the above results support the first hypothesis which says that "Each of the suggested determinant of audit fees thought to be of high importance for the two groups of respondents: external auditors and client representatives which includes financial controllers, accountants and internal auditors". So hypothesis one can be accepted. It is clear that the above table suggests that all factors were thought to have a relative importance on audit fees for all groups taken together and for each group alone.

The second step is test whether the two groups rated the importance of each factor homogeneously or differently. But for testing the second hypothesis which says, "The degree of importance of each determinant of audit fees is homogenous among the different groups of respondents, external auditors and client representatives" further analysis had been made. Mann-Whitney U test was conducted .The Mann-Whitney U Test is normally used to compare differences between two independent groups when the dependent variable is either ordinal or interval but not normally distributed. It is the nonparametric alternative to the independent t-test. As mentioned previously, two groups of respondents were surveyed, namely external auditors, client representatives (financial controllers, accountants and internal auditors). Each group of respondents revealed their views concerning the relative importance of the determinants of audit fees. The analysis tested whether the differences in the means for each factor was statistically significant or not significant.

The null hypothesis is that all means are the same and it is tested against the hypothesis that not all means are equal; i.e. there is a significant difference in the views of external auditors and client representatives concerning each one of tested determinants of audit fees.

$\mathrm{H}_{0}: \mu_{\mathrm{EAUD}}=\mu_{\mathrm{FC}}=\mu_{\mathrm{ACC}}=\mu_{\mathrm{IAUD}}$

$\mathrm{H}_{1}$ : Not all means are equal

The following table summarizes the results of Mann-Whitney U test:

Table 2. Mann-Whitney U test

\begin{tabular}{lllllll}
\hline & Factor 1 & Factor 2 & Factor 3 & Factor 4 & Factor 5 & Factor 6 \\
\hline Mann-Whitney U & 634 & 658 & 696 & 742 & 766 & 730 \\
Wilcoxon W & 1229 & 1253 & 1291 & 1337 & 1847 & 1325 \\
Z & -1.8978 & -1.2571 & -0.893 & -0.4074 & -0.1613 & -0.5498 \\
Asymp. Sig. (2-tailed) & 0.0577 & 0.2087 & 0.3718 & 0.6837 & 0.8719 & 0.5824 \\
\hline & Factor 7 & Factor 8 & Factor 9 & Factor 10 & Factor 11 & Factor 12 \\
\hline Mann-Whitney U & 718 & 648 & 620 & 660 & 764 & 678 \\
Wilcoxon W & 1313 & 1243 & 1215 & 1255 & 1359 & 1759 \\
Z & -0.6514 & -1.3869 & -1.6875 & -1.227 & -0.1828 & -1.1128 \\
Asymp. Sig. (2-tailed) & 0.5148 & 0.1655 & 0.0915 & 0.2198 & 0.8549 & 0.2658 \\
\hline
\end{tabular}

Mann Whitney $U$ test results show that there is insignificant difference in the mean ranking of all of the pre-suggested determinants of audit fees between the two groups of respondents (External auditors and client 
representatives). In other words, there is insignificant difference between the median of the two groups of respondents. As the p value is greater than 0.05 , the null hypothesis should be accepted that there is no significant difference in means ranking. These results support the second hypothesis of the research which says "The degree of importance of each determinant of audit fees is homogenous among the different groups of respondents".

\section{Conclusion and Recommendations}

It can be concluded that all the factors examined in this study were found to be important for the two groups taken together or for each group alone. Also, it had been found that the two groups of respondents had rated the importance of each factor homogeneously. It should be emphasized that being one of the big-four was found to be the most important factor in affecting determining the amount of audit fees from view-points of both groups of respondents. This is consistent with what the external auditors said in the interviews as mentioned before. Multinational firms and banks in Lebanon prefer to pay more to the big-four as they seek quality of the audit work and to increase credibility of their annual reports all over the world. For future research, the researcher thinks that it will be great if the law in Lebanon can enforce companies to publish its audit fees figure in their annual reports so we can examine through the use of regression analysis if these factors examined in the present study affect the determination of audit fees figure not on attitudes or views of different groups of respondents as we did in our present study.

\section{References}

AICPA. (1983). Audit risk and materiality in conducting an audit, statement on Auditing standards No.47, American institute of certified public accountants.

Anderson, T., \& Zeghal, D. (1994). The pricing of audit services: further evidence from the Canadian market. Accounting and Business Research, 24(95), 195-207. http://dx.doi.org/10.1080/00014788.1994.9729479

Butterworth, S., \& Houghton, K. A. (1995). Auditor switching:The pricing of audit services. Journal of Business Finance and Accounting, 22(3), 323-344. http://dx.doi.org/10.1111/j.1468-5957.1995.tb00877.x

Carson, E., Fargher, N., Simon, D., \& Taylor, M. (2004). Audit fees and market segmentation-further evidence on how client size matters within the context of audit fees models. International Journal of Auditing, 8(1), 79-91. http://dx.doi.org/10.1111/j.1099-1123.2004.00159.x

Chan, P., Ezzamel, M., \& Gwilliam, D. (1993). Determinants of audit fees for quoted UK companies. Journal of Business Finance and Accounting, 20(6), 765-86. http://dx.doi.org/10.1111/j.1468-5957.1993.tb00292.x

Che Ahmed, A., \& Houghton, K. A. (1996). Audit fee premiums to big eight firms: evidence from the medium-size UK audittees. Journal of International Accounting, Auditing and Taxation, 5(1), 53-72. http://dx.doi.org/10.1016/S1061-9518(96)90015-4

Choi, Jong-Hag, Kim, Chansog, Kim, Jeong-Bon, \& Zang, Yoonseok. (2010). Audit Office Size, Audit Quality, and Audit Pricing. Auditing: A Journal of Practice \& Theory, American Accounting Association, 29(1), 73-97.

Chung, D. Y., \& Lindsay, W. D. (1998). The pricing of audit services: the Canadian perspective. Contemporary Accounting Research, 5(3), 19-46.

Chung, S., \& Narasimhan, R. (2002). An international study of cross-sectional variations in audit fees. International Journal of Auditing, 6(1), 79-91. http://dx.doi.org/10.1111/j.1099-1123.2002.tb00006.x

Craswell, A. T., Francis, J. R., \& Taylor, S. L. (1995). Auditor brand name reputations and industry $\begin{array}{llll}\text { specialisations. Journal of Accounting and Economics, 20(3), 297-322. } & \text {. }\end{array}$ http://dx.doi.org/10.1016/0165-4101(95)00403-3

Craswell, A., \& Francis, J. R. (1999). Pricing initial audit engagements: a test of competing theories. The Accounting Review, 74(2), 201-16. http://dx.doi.org/10.2308/accr.1999.74.2.201

Cullinan, C. (1998). Evidence of non-big 6 market specialization and pricing power in a niche assuming service sector. Auditing, A Journal of practice and theory, 17(supplement), 47-57.

DeAngelo, L. E. (1982). Auditor Size and Audit Quality. Journal of Accounting and Economics, 3(3), 183-191. http://dx.doi.org/10.1016/0165-4101(81)90002-1

Dugar, A., Ramanan, R., \& Simon, D. T. (1995). A comparative study of the audit services market for public sector versus private sector companies in India. Advances in International Accounting, 10, 1-13. 
Ezzamel, M., Gwilliam, D. R., \& Holland, K. M. (1996). Some empirical evidence from publicly quoted UK companies on the relationship between the pricing of audit and non-audit services. Accounting and Business Research, 27(1), 3-16. http://dx.doi.org/10.1080/00014788.1996.9729528

Ezzamel, M., Gwilliam, D. R., \& Holland, K. M. (2002). The relationship between categories of non-audit services and audit fees: evidence from UK companies. International Journal of Auditing, 6(1), 13-35. http://dx.doi.org/10.1111/j.1099-1123.2002.tb00003.x

Ferguson, A., Francis, J., \& Stokes, D. (2003). The effect of firm-wide and office-level industry expertise on audit pricing. The Accounting Review, 78(2), 429-48. http://dx.doi.org/10.2308/accr.2003.78.2.429

Firth, M. (1985). An analysis of audit fees and their determinants in New Zealand. Auditing a Journal of Practice and Theory, 4(2), 23-37.

Firth, M. (1997). The provision of non-audit services and the pricing of audit fees. Journal of Business Finance and Accounting, 24(3), 511-25. http://dx.doi.org/10.1111/1468-5957.00118

Francis, J. R. (1984). The effect of audit firm size on audit prices: a study of the Australian market. Journal of Accounting and Economics, 6(2), 133-51. http://dx.doi.org/10.1016/0165-4101(84)90010-7

Francis, J. R., \& Simon, D. T. (1987). A test of audit pricing in a small-client segment of the US market. The Accounting Review, 62(1), 145-57.

Francis, J. R., \& Stoke, D. T. (1986). Audit prices, product differentiation and scale economics: further evidence from Australian market. Journal of Accounting Research, 24(2), 383-93. http://dx.doi.org/10.2307/2491141

Gonthier, B., \& Schatt, A. (2007). Determinants of audit fees for French quoted firms. Managerial Auditing Journal, 22(2), 139-160. http://dx.doi.org/10.1108/02686900710718654

Hackenbrack, K., \& Knechel, R. (1997). Resource allocation decisions in audit engagements. Contemporary Accounting Research, 14(3), 481-99. http://dx.doi.org/10.1111/j.1911-3846.1997.tb00537.x

Haskin, M. E., \& Williams, D. D. (1988). The association between client factors and audit fees: a comparison by country and firm. Accounting and Business Research, 18(70), 183-90. http://dx.doi.org/10.1080/00014788.1988.9729363

Hay, D., Knechel, W. R., \& Wong, N. (2006). Audit fees: a meta-analysis of the effect of supply and demand $\begin{array}{llll}\text { attributes. } & \text { Contemporary Accounting }\end{array}$ http://dx.doi.org/10.1506/4XR4-KT5V-E8CN-91GX

Iyer, V. M., \& Iyer, G. S. (1996). Effect of Big 8 mergers on audit fees: evidence from the UK. Auditing: A Journal of Practice and Theory, 15(2), 123-31.

Joshi, P. L., \& Al-Bastaki, H. (2000). Determinants of audit fees: evidence from the companies listed in Bahrain. International Journal of Auditing, 4(2), 129-38. http://dx.doi.org/10.1111/1099-1123.00308

Kutob, A., \& Al-Khater, K. (2004). An empirical investigation of factors affecting audit fees: The case study of Qatar. King Abdul-Aziz University Journal for Economics and Management, 18(2), 153-188.

Larcker, D., \& Richardson, S. (2004). Fees paid to audit firms, accual choices and corporate governance. Journal of Accounting Research, 42(3), 625-58. http://dx.doi.org/10.1111/j.1475-679X.2004.t01-1-00143.x

Longuenesse, E. (2006). Accountants and economic governance in a dependent country: conflicting legacies and new professional issues in Lebanon. Society and Business Review, 1(2), 106-121. http://dx.doi.org/10.1108/17465680610669807

Low, L. C., Tan, P. H. N., \& Koh, H. C. (1990). The determinants of audit fees: an analysis in the Singapore context. Journal of Business Finance and Accounting, 17(2), 285-95. http://dx.doi.org/10.1111/j.1468-5957.1990.tb00561.x

Maher, M., Tiessen, P., Colson, R., \& Broman, A. (1992). Competition and audit fees. The Accounting Review, 67(1), 199-211.

Mike, A., Mike, S., \& Muhammad, H. (1997). The determinants of external audit costs in the New Zealand life insurance industry. Journal of International Financial Management and Accounting, 8(1), 69-86. http://dx.doi.org/10.1111/1467-646X.00018

Naser, K., \& Nuseibeh, R. (2007). Determinants of audit fees: empirical evidence from emerging economy. International Journal of Comerce and Management, 17(3), 239-254. 
Niemi, L. (2002). Do firms pay for audit risk? Evidence on risk premiums in audit fees after direct control for audit effort. International Journal of Auditing, 6(1), 37-51. http://dx.doi.org/10.1111/j.1099-1123.2002.tb00004.x

Palmrose, Z. (1986). Audit fees and auditor size: Further evidence. Journal of Accounting Research, 24(1), 97-110. http://dx.doi.org/10.2307/2490806

Pearson, T., \& Trompeter, G. (1994). Competition in the market for audit services: the effect of supplier concentration on audit fees. Contemporary Accounting Research, 11(1), 115-135. http://dx.doi.org/10.1111/j.1911-3846.1994.tb00439.x

Sandra, W. M. H., \& Patrick, P. H. N. (1996). The determinants of audit fees in Hong Kong: an empirical study. Asian Review of Accounting, 4(2), 32-50. http://dx.doi.org/10.1108/eb060673

Sidani, Y. M. (2007). The auditor expectation gap: evidence from Lebanon. Managerial Auditing Journal, 22(3), 288-302. http://dx.doi.org/10.1108/02686900710733152

Simon, D. T. (1995). The market for audit services in South Africa. International Journal of Accounting, 30(4), 356-65.

Simon, D. T., \& Taylor, M. H. (2002). A survey of audit pricing in Ireland. International Journal of Auditing, 6(1), 3-12. http://dx.doi.org/10.1111/j.1099-1123.2002.tb00002.x

Simon, D. T., Ramanan, R., \& Dugar, A. (1986). The market for audit service in India: an empirical examination. International Journal of Accounting, Spring, 27-35.

Simon, D. T., Teo, S., \& Trompeter, G. (1992). A comparative study of the market for audit services in Hong Kong, Malaysia and Singapore. International Journal of Accounting, 27, 234-40.

Simunic, D. A. (1980). The pricing of audit services: Theory and Evidence. Journal of Accounting Research, Spring, 161-190. http://dx.doi.org/10.2307/2490397

Stice, J. (1991). Using financial and market information to identify pre-engagement factors associated with lawsuits against auditors. The Accounting Review, 66(3), 516-533.

Taylor, M. H. (1997). The market of audit services in Japan. Pacific Accounting Review, 9(2), 59-74.

Taylor, M. H., Simon, D. T., \& Greg Burton, F. (1999). A survey of audit service pricing in South Korea. Research in Accounting Regulation, 13, 201-7.

The World Bank. (2003). Report on the observance of standards and codes (ROSC), Republic of Lebanon. Acounting and Auditing, World Bank.

WaresulKarim, A. K. M., \& Moizer, P. (1996). Determinants of audit fees in Bangladesh. International Journal of Accounting, 31(4), 497-509. http://dx.doi.org/10.1016/S0020-7063(96)90034-5 